\title{
An Analysis of Future Delinquency for Hotel CMBS Loans
}

Cornell Haspitality Quarterly

5 । (4) 457-458

(c) The Author(s) 2010

Reprints and permission:

sagepub.com/journalsPermissions.nav DOI: 10.1 | 77// 9389655 1038। 050

http://cqx.sagepub.com

\author{
By John B. Corgel and Aaron Walls
}

\begin{abstract}
The hotel industry seems to be recovering from its recent abyss, but the financial damage to many properties from many months of decline will continue for some time. In particular, the hotel industry faces the prospect of heavily leveraged properties submerged by delinquencies and defaults. An analysis of debt coverage ratios for 365 hotel properties with commercial mortgage-backed security loans shows considerable deterioration from 2008 to a nadir in 2010. Starting in $201 \mathrm{I}$, net operating income and debt coverage ratios should gradually improve, with noticeable improvement in 2012 .
\end{abstract}

\section{Keywords}

CMBS, debt, delinquency, loan portfolios, debt coverage
Many questions remained as to the overall health of the U.S. economy as we entered the third quarter of 2010 . However, lodging market participants enjoyed a recovery in demand during the first half of 2010 that has exceeded expectations. While this is positive news, the depth of the industry contraction reached record levels. Colliers PKF Hospitality Research (Colliers PKF-HR) reports that the average hotel in their 2010 Trends ${ }^{\circledR}$ in the Hotel Industry sample realized a 35.4 percent decline in unit-level profitability. This is the single greatest decrease since the firm began tracking these data in 1936. This decline in hotel profitability (recorded as net operating income, or NOI) has serious implications for both hotel owners and their lenders. Mortgage delinquency and default represent a challenge to near-term recovery of normal capital flows to the industry. The results from our recent study of hotel mortgage loan problems provide evidence that the severity of these problems will lessen in 2012.

Almost daily reports from the financial press and securities analysts document an emerging problem in the banking and securitized loan sectors of potentially gigantic proportions stemming from weakening commercial real estate (CRE) cash flows and property prices that have already begun to manifest in loan delinquencies, defaults, and monetary losses. ${ }^{1}$ As property values sink below loan balances, borrowers become increasingly incentivized to withhold payments and relinquish ownership to lenders. Recent foreclosure experience in the U.S. housing markets seems certain to be repeated in the CRE markets.

Hotel real estate occupies a position at the leading edge of the coming CRE storm. Without lease contracts, hotels have direct exposure to demand downdrafts. Overbuilding in hotel markets also has been a problem during some previous recessions as supply growth continues in the presence of sudden drop-offs in demand. A carefully performed analysis of impending financial stress resulting from hotel loan delinquency and default has important implications for benchmarking the severity of impending CRE loan problems among banks and commercial mortgage-backed security (CMBS) investors and for forecasting future capital flows in the hotel sector.

Colliers PKF-HR has developed automated financial planning tools to forecast hotel NOI and property values that, when combined with debt service obligations and loan amounts, enable objective estimations of future hotel loan performance. Using this approach, Colliers PKF-HR was able to prepare a thorough examination of the potential for the future delinquency of 365 hotel CMBS loans. Summarized below, this analysis is invaluable to special servicers, lenders, investors, operators, attorneys, and government regulators.

\section{Estimates of Future Delinquency}

The debt coverage ratios (DCRs) of the 365 hotels for which we estimated debt service payments and NOIs through 2012 are shown in Exhibit 1 for each year beginning in 2008. According to the 2010 Colliers PKF-HR Hospitality Investment Survey, lenders require DCRs for hotels equal to approximately 1.5. Below this level, a hotel loan may approach loan covenant levels that eventually may lead to technical default if additional equity is not invested by borrowers. At a DCR of less than 1.0, loans are in serious jeopardy of delinquency. Exhibit 2 provides a graphical view of the same results. 
Exhibit I. Debt Coverage Ratios (DCRs) for Hotel Sample $(\mathrm{N}=365), 2008-2012$

\begin{tabular}{lrrrrr}
\hline & \multicolumn{5}{c}{ Year } \\
\cline { 2 - 6 } DCR & 2008 & 2009 & 2010 & 2011 & 2012 \\
\hline Above 3 & 63 & 32 & 35 & 42 & 54 \\
2 to 2.99 & 120 & 49 & 51 & 66 & 114 \\
I.5 to 1.99 & 96 & 68 & 72 & 106 & 90 \\
I.3 to 1.49 & 29 & 58 & 48 & 40 & 38 \\
I.I5 to 1.29 & 18 & 30 & 38 & 25 & 24 \\
I to I.14 & 13 & 30 & 26 & 22 & 8 \\
Less than I & 27 & 98 & 95 & 64 & 37 \\
\hline Total & 365 & 365 & 365 & 365 & 365
\end{tabular}

Source: Trepp, UC, Colliers PKF Hospitality Research.

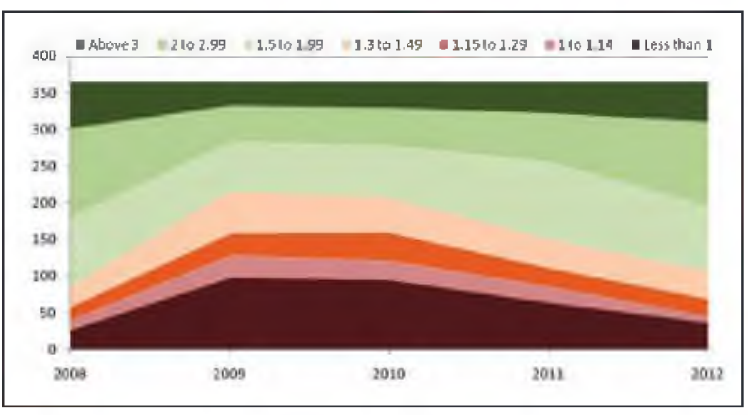

Exhibit 2. Graphical Presentation of Debt Coverage Ratios (DCRs) for Hotel Sample $(N=365), 2008-2012$

Source: Trepp, UC, Colliers PKF Hospitality Research.

At the beginning of the study period in 2008,87 of the 365 hotels had DCRs less than 1.5, of which 27 were less than 1.0. Our DCR estimates for 2010 indicate a clear deterioration of loan security. Of the 365 hotels, 95 ( 26 percent) have estimated DCRs less than 1.0, and 207 (57 percent) have DCRs below 1.5. The percentage of hotels with DCRs below 1.0 exceeds the 18 percent delinquency rate for hotel loans reported by Fitch, suggesting the potential for delinquency has not been fully reached. Fitch also forecasts the hotel delinquency rate to reach 30 percent by $2012 .^{2}$ Our analysis, based on econometric forecasts of hotel room revenues and modeled NOIs, reveals improvement of hotel loan security and a return to approximately the 2008 delinquency level by 2012. We expect the peak of CMBS hotel loan problems to occur in 2010 , but we expect only gradual improvement in 2011. By 2012, hotel NOI growth should begin to relieve some of the stress on hotel delinquency.

\section{Conclusion}

The financial environment in which hotels operate has deteriorated precipitously since the end of 2007, and years 2010 and 2011 will be extremely challenging for hotel operators, owners, and special servicers. With almost more than a quarter of the CMBS loan portfolio unable to meet debt service obligations, the special servicers of those loans will need to understand if properties can be worked out or should be liquidated. We are the first to directly examine individual hotels' ability to pay when forecasting hotel loan performance issues. The results of our analyses demonstrate a clear peak in hotel delinquencies during 2010, with 2011 showing an increase in NOI performance that relieves the downward pressure of the preceding two years.

A report on hotel default based on the relationship between future hotel property values and loan balances will follow this analysis.

\section{The Full Report}

A full description of the research methodology and results can be found in the 2010 edition of Trends ${ }^{\circledR}$ in the Hotel Industry. To purchase a copy of the 2010 Trends (B) report, please visit our webstore at www.pkfc.com/store, or call 866-842-8754.

\section{Disclosures}

The author(s) declared no conflicts of interest with respect to the authorship and/or publication of this article.

\section{Funding}

The author(s) received no financial support for the research and/or authorship of this article.

\section{Notes}

1. See, for example, Pewter Eavis, "Lenders Open to Real-Estate Pain," Wall Street Journal, April 10, 2010. The first sentence in this article is, "A slow motion train wreck is still a train wreck."

2. See "US Hotel Loan Default Rate May Double by 2010_Fitch," Reuters, March 22, 2010.

\section{Bios}

John B. (Jack) Cor gel, Ph.D., the Robert C. Baker Professor of Real Estate at the Cornell University School of Hotel Administration, assists Colliers PKF Hospitality Research in an advisory capacity (jc81@cornell.edu). Aaron Walls is a research analyst with Colliers PKF Hospitality Research (aaron.walls@pkfc.com). 